Vol. 6, No. 1, 2019

https://doi.org/10.23939/eem2019.01.013

UDC 657.412.7 (477.8) "18/19"; 005.21

JEL Classification Code M41, B15, N01

I. Yaremko

Lviv Polytechnic National University, Ukraine, Doctor, Professor

E-mail: I.Yaremko@i.ua

ORCID: 0000-0003-4624-7634

O. Lemishovska

Lviv Polytechnic National University, Ukraine, $\mathrm{PhD}$, Associate Professor

E-mail: leslem@ukr.net

\title{
RESERVE AND REGULATORY OBJECTS IN ACCOUNTING THEORY AND PRACTICE: ORIGINS AND EVOLUTION OF THE WORLD ACCOUNTING THOUGHT WITHIN THE FRAMEWORK OF THE DEVELOPMENTS BY THE WESTERN UKRAINIAN SCIENTISTS OF THE 19TH - MIDDLE 20TH CENT. (OPINION FROM THE MODERN AGE PERSPECTIVE)
}

\begin{abstract}
There are growing risks in the conduct of financial and economic activities by economic agents in the conditions of the modern economy, and because a reliable information base is needed both for management purposes and for market counterparties regarding the means actually available at an enterprise to overcome the risk of loss (reduction) of capital. Accounting and public reporting is the only tool that provides information in formalized data on the size of the reserve and insurance potential established by an entity. However, there are a number of problematic issues in modern theory and practice regarding the objective display of reserve and regulatory objects in the accounting and their provision in the public financial (corporate) reporting that actualize the multi-vectoral research both in the subject area of knowledge and in the system of interdisciplinary researches. The hypothesis of this research is the assumption of elaboration in past developments, including Western Ukrainian scholars, relevant to the modern theory and practice of ideas that can objectively be considered appropriate for the improvement of modern accounting of capital reserves, a means to enhance the validity of managerial decisions to a more adequate information provision. The article analyses the historical stages of the development of reserve and regulatory objects of accounting, evaluates
\end{abstract}

the fundamental principles of the formation of accounting reserves in different accounting concepts in the evolutionary aspect by distinguishing the relevant ones among them for modern research. The scientific legitimacy of the ways and approaches proposed in this article to improve the conceptual foundations of the reservation system in modern accounting rests upon the use of historically formed ideas and is based on the following approaches: it is argued that accounting tools are an important component of any paradigm of reserve management, the only formalized information tool for disclosing the real state of the security of the capital employed by an enterprise; the formation of reserves is a consequence of one of the principles of accounting - the assumption of continuity of an enterprise, embodied in the modern concept (paradigms) of sustainable development. Using general scientific and interdisciplinary methods of cognition, traditional methods for historicalanalytical analysis (historical and retrospective, historical and comparative methods) and the techniques special for the sphere of accounting, the theoretical generalization was conducted of systematic approaches to organization of computational practise, evolutionary disposition of reserve and regulatory articles in accounting system and their characteristic positioning in separate accounting concepts and theories. A separate 


\section{Yaremko, O. Lemishovska}

component of the study is the historiographical analysis and assessment of accounting reservation in unexplored works of Western Ukrainian theoreticians and in the practice of accounting. On the basis of the performed exploration, the following reasoning was provided regarding the author's conclusions about the appropriateness of the use of certain aspects of the historical developments in respect of regulatory principles in modern norms and regulation in any system of accounting standardization and the suggestions were substantiated about ways to adapt public accounting and financial reporting needs of modern economic conditions. On the basis of the received results, the expediency of use of approaches and techniques of organic and econometric balance theories was substantiated for the development of modern accounting reserve and regulatory objects, which confirms the relevance of research of such direction in general, and of this one in particular.

Key words: accounting, balance theories, objects, reserves, reserve capital, reserve funds, regulators, targeted financing, provision, methodology.

\section{Introduction}

The instability of the general economic environment in economies of any type objectively and naturally leads to an increase in risks in various processes of the functioning of economic entities. Such natural circumstances cause the need for economic entities to create their own protective functions in the form of various tools and financial instruments. High degree of uncertainty of the modern business environment and unpredictable appearance in it of multifactorial risks and factors of negative impact on the stable activity of the economic structures actualize the task of developing the protection tools of the capital involved in turnover, which are effective in practice. The search for efficient management structures capable of supporting sustainable functioning of entities is identified primarily with the creation of reserve system adequate to the economy-wide conditions, which is capable of neutralizing or minimizing the effects of external environmental impact. Formation of the system of effective tools for management technologies oriented to such purposes is carried out involving the accounting information in this system concerning reserve and insurance objects (formation of compensation sources in the accounting system). In many cases, it is recognized that in the context of developing a protective mechanism for a particular enterprise, "the problem of accounting and analytical support that meets the needs of actual reserves managing becomes of particular relevance" [1, p. 213].

The reserves imperative for accounting (reserve capital) and allowable reserves of economic character (reserves of potential opportunities) and reservation objects numerous for such content and destination, which are additionally formed in accounting according to the statutory regulations of a particular enterprise or defined for the needs of increasing the rationality of management system, provide the system of protective functions of an enterprise selected and implemented in practice systematically and in conjunction with other instruments. In terms of creating a backup (insurance) and regulatory objects, the accounting system is a tool of soft infrastructure, including in the management of deliberately risk operations (insurance of the possible loss of core capital). Compared with other tools for managing capital reserves, the accounting and reporting system is distinguished by the fact that it reflects a standardized system of indicators that reveals the target orientation of the formed objects. From a theoretical point of view, it is rightfully to assume that in the financial instruments (methodological and methodical arsenal), the appropriate mechanisms were laid down to counter risks (for example, blocking the process of distribution of profits, using them as a source of creation of reserves and making it impossible to output the part of a functioning capital from a company). From this point of view, it is right to consider that the adequacy of the accounting methodology for reserve objects makes it possible to increase the efficiency of management in the parameters of the risk management concept.

Despite the existing system of modern principles of formation of accounting reserves (accounting regulations and recommendations), theoreticians and practitioners noted the possibility of manipulating accounting methodology in relation to this type of objects. In particular, the emphasis is on inadequate quality verification of these objects, which reduces the objectivity and transparency of financial reporting, causing the 
emergence of information risks, primarily for external users. Accounting novations that were spread through the "advisory" nature of international and national standardizations of financial reporting, in many cases allow ambiguous idea of the reflected potential of an enterprise's capability of stable operation over the security of working capital. Specifically, the balance as a public form of reporting should not only represent an opportunity to cover company's liabilities with its assets, but also disclose the extent of the provision of enterprise with safety and insurance sources to save cost of the capital employed (assessment of credit and investment risk, risk of bankruptcy, etc.).

Based on existing problems in modern practice, there is a clear need to improve the methods of forming a more adequate system of accounting reserve and regulatory objects. To address these problems, scientists often substantiate the practicality of referral to past developments in respect of such objects (methodological arsenal in the subject field of knowledge), some ideas in which are recognised as appropriate and relevant for modern developments: "the study of the condition of the reservation systems is impossible without a historical understanding of their formation and development" [3, p. 68]; "the search for ways to overcome existing problems and improve the accounting of reserves is associated with the study of the stages of their development and implementation in accounting" [4, p. 130]. In general, it can be noted that in a large number of issue-related works, it is recognized that "the topic of the historical development of reserves and the study of the views of various scholars on their reflection in accounting is relevant" [5, p. 211].

Depreciation and wear of the core capital are considered as similar objects in the article, which also form the idea of external users on the level of loss of the initial value of fixed capital (physical and moral deterioration of economic resources).With the technological development and constitutional significance of intangible component in the economic potential of modern business entities, the problems of calculating the wear and depreciation of fixed capital and their displaying in the accounting system became more intensified, actualising the scientific research towards the production and substantiation of the accounting concept of depreciation and wear-and-tear of fixed economic resources that is adequate for modern economy. The view on deprecation and wear-andtear of either reserve, regulatory or stock (accumulation of target capital) objects in the entire evolution of accounting remains uncoordinated. The conclusion made by well-known scholars in the field of accounting is relevant for both past accounting concepts and for the modern accounting system: ".... the expressions "deprecation" and "deprecation provision" confuse both those who read the accounting statements and the accountants themselves" [2]. As well as in relation to the reserves, the researchers substantiate the expediency of applying to the past works and in developing the modern concept of depreciation: "in order to improve accounting of operations on accrual of depreciation of the fixed assets at the current stage, it is necessary to take into account the experience and achievements of past generations, use the results of searches of their predecessors and use the knowledge and skills acquired by them" [6, p. 482]; "it is expedient to conduct in-depth studies of the economic essence of the accounting concept of depreciation in its historical development" [7].

The information presented reveals a general view on the existing theoretical and applied problem, substantiates the scientific validity of the direction, as well as the nature and relevance of this study.

\section{Literature review}

Results of the analysis of the works by scientists from different countries confirm that there are numerous problems of conceptual, methodological and systematic nature in the modern accounting of reserve and regulatory objects, the problems of objective calculation by accounting methods of wear and deprecation of fixed assets. Historiographic analysis of the formation of systems of reservation and expression of regulatory objects in accounting also proves that these objects during the entire evolution of accounting have also been the subject of discussion in various national schools and scholars. In particular, as M. O. Kozlova states, despite the fact that during the whole historic period, "the scientists 


\section{Yaremko, O. Lemishovska}

debated about the inclusion of an accounting object in the reserve, fund, capital or regulative category, but the conventionality about these concepts was not achieved even until the early 21st century". [8] Yu. V. Pikush and L. M. Pylypenko also note that at present "many aspects of the theoretical positions in the research of scientists are recognized as speculative regarding the correctness of the use of such concepts as "reserve", "reserve capital", "fund", "regulator", "provision" [5, p. 211]

The analysis of the content and the results of recent research and publications also indicates the lack of a precise and formalized conceptual categorical apparatus in the field of accounting reserves and regulations. Lack of clear content of accounting objects of this type causes the problem of the methodological basis of the accounting system in general, depriving the unambiguous methodology of accounting for individual objects of this group. For example, D. I. Ponokova, based on the results of a targeted scientific research on the modern accounting of such objects, makes the following conclusion: "the reserves, which are formed in the accounting statements are purely financial in nature, ... they do not represent any stocks or values, and the financial result is reserved and the evaluation of the main objects of accounting surveillance is determined (revenue, expenses, assets, equity and liabilities)" [9]. A similar conclusion regarding the accounting and audit of capital reserves was obtained on the basis of the results of the case study by M. M. Oryshchenko [10].

In many modern researches, the unresolved question of mixing reserve and regulatory articles is also referred to the speculative moments specification of objects due to the content, subordination and disposition of financial accounts in the general conceptual and methodological basis of accounting within any standardization. It is noted in research that with regard to depreciation and wear, there are still no mutually acceptable terms - such account that is common for the modern practice of accounting called "Wear-andtear (depreciation) of non-current assets" is considered regulated as relating to the account "Non-current assets", or the stock one, i.e. such that it shows the assembled sources of funds for their restoration. In this context, Ya. V. Sokolov points out that "the diametrically opposite understanding of depreciation by two worldrenowned schools (institutionalist - as a reserve, personalistic - as a regulator) was one of the differences in the interpretation of modern accounting theory" [11]. The identification of depreciation with a depreciation fund by the known scientist G. Hatfield described as follows: "Only sick imagination of people can recognize the depreciation as a fund"; this position was supported by J. Chenaux-Repond: "it is absolutely unclear how a source of cash flow is formed from the value of the object of the basic means that decreases as a result of its operation, which in addition must act as a source of renovation" [12, p. 161]. A similar view was followed by another well-known scientist of the German accounting school A. Römer: "it is unknown with which means of amortization the reserves are created as it is a loss of property" [13, p. 17].

Regarding the achievements of Western Ukrainian scholars in the nineteenth and midtwentieth centuries, where the principles of the German accounting school dominated, we will note that they remain largely unexplored, and the source base developed by us gives enough evidence to draw a significant place for such objects in their development $[14 ; 15 ; 16 ; 17 ; 18 ; 19 ; 20 ; 22 ; 23$; 24]. We will only briefly indicate here the importance of these objects in their development. Thus, in the work "Cost in the Economy and in the Balance Sheets" [22] in the section "Accounting of the Components of Property" (original "Konta składników majątkowych"), the considerable attention is given to the part of the capital, especially to the reserve funds. The author's technique of displaying the formation and use of reserve funds in the accounts of contributions to capital (original "Konta wkładek kapitałowych") is presented. In the work [15], Au Juliusz also highlights the issue of accounting of the reserve capitals because of the value of the components of the valued property (original "Szacowanie czyli oznaczenie wartości części składowych majątku”).

When considering accounting systems (original "Formy rachunkowe"), the positioning of regulatory articles in accounting systems with a critical analysis of their reflection in accounting was considered in the work [16]. Similarly, the 
reserve and regulatory objects of accounting are set out in the textbook "Theoretical and Practical Accounting" [14], where these objects are classified as the main objectives of accounting. When considering the accounts for trading enterprises in the textbook [20], the reserve accounts are given a fundamental role among all capital accounts in the formation of the basic foundation of accounting. In this case, their important role in the processes of calculating the cost of capital (original "Obliczenie kapitału końcowego", “Obliczenie kapitanłu początkowego, zasu i stopy procentowe”). In particular, in section $\mathrm{V}$ of the textbook called "Use of Accounting in Public Commercial Companies" (original "Zastosowanie księgowości pojedynczej jawnych w spółkach handlowych") and in the section VI called "Accounting of Partnership Interests" (original "Księgowanie interesów partycypacyjnych"), back-up and regulation accounts are positioned as such that have a significant place in the accounting in terms of insurance of a public company's own capital, and their guidance in reporting is the information potential for partners.

The most detailed capital reserves are disclosed when developing the econometric balance theory [17]. In particular, in the section VII called "Grouping of Assets and Capital" (original "Gruppierung des Vermögens und Kapitals"), "Reserve Assets and Reserve Capital (original "Reservevermögen und Reservekapital") were separately identified, interconnected and considered. "General Information on Reserve Funds" (original "Allgemeines über Reservefonds") is primarily considered in details in the textbook with allocation of accounting display of information about the "Real Backup Funds" (original "Wirkliche Reservefonds") and "Anticipative Provisions" (original "Antizipativ-Reserven"), i.e. those that are formed by the expected events. The accounting of objects on the "Hidden Reserves" (original "Stille Reserven") and the "External (Neutral) Reserves" (original "Fremde (neutral) Reserven") have been selected and proposed. To ensure the accounting methodology of these objects, the "Reserve Capital Accounts" (original "Reservekapitalkonten"), "Capital Reserve Accounts" (original "Kapitalreservekonten") were substantiated. The traditional objects that are filed as "False Reserves" (original "Falsche Reserven") were critically considered. The cost measurement of reserve and regulatory objects was generalized, for which the "Evaluation of Reserve Capital" (original "Die Bewertung der Reservekapitalien") and "Evaluation of Capital Reserves" (original "Die Bewertung der Kapitalreserven") were proposed.

To underline the existence of weighty developments, we will provide the historiographic sources of information that indicate the recognition by modern foreign scientists of the importance of developments by Western Ukrainian theoreticians and practitioners for the world theory of accounting. For example, T. V. Yeriomenko, while conducting a critical analysis (2016) of the global and German concepts of accounting depreciation indicates that " $\mathrm{P}$. Ciompa, as far back as in 1910, distinctly outlined one of the problems of contemporary German accounting the contradiction between the principles and methods of depreciation, in particular arguing that an indirect way to display amortization leads to overestimation of the balance sheet, coming into conflict with the requirements of comprehensibility (Bilanlanzklarheit) and the objectivity of balance (Bilanzwahrheit) [25, p. 13].

Results of the analysis of the literature sources of historiographic character in relation to recognized international development and processing of previously unexplored developments by Western Ukrainian theoreticians and practitioners allow us to formulate a conclusion that the main problems of the formalized measuring of reserve and regulatory facilities during the evolution of accounting system are connected with the fact that different types of capital reserving have distinctive characteristics, are difficult in being subjected to either formalization or cost verification, and therefore are accounted differently [26]. Regarding the problems of accounting of reserve and regulatory objects, the relevant recognition issues, valuation issues and classification issues are put forward. The works of the leading scientists indicate that the substantiated formation of reserve and regulatory objects and also currently "can be defined only by clear formulations, because there are no analogues in the real world to them" [27, p. 205]. 


\section{Yaremko, O. Lemishovska}

The purpose of the article is the study of the economic nature evolution of reserve and regulatory objects and parameters of the conceptual and methodological foundations of their accounting display, the historiographical analysis of methodical and procedural principles in the developments of the world accounting thought and in the developments of Western Ukrainian scientists, as well as formulation of proposals on their basis regarding the use of certain ideas of past developments for the improvement of modern accounting and reporting.

\section{Methodological approach}

The methodological basis of the study consists of general scientific methods and methods of scientific perception that are special for the subject area of knowledge. The selection of appropriate methods is due to the nature, subject and defined purpose of this study. The current research methodology provides a wide range of research components: analysis of the results of publications, which reveals the problems of modern accounting of reserve and regulatory objects; generalization of scientific and research sources of historiographical character, investigating the rational aspects of the accounting of reserves during historical evolution; elaboration of previously unexplored scientific and applied developments of Western Ukrainian theoreticians and practitioners. The outstanding spectrum and coordinates of the study determine the use of system methodological arsenal. The scientific and educational methods of abstracting and concretization were used as basic, which provided the opportunity to borrow experience from conducting historical and economic research on the formation of an evolutionary idea about the subject of research. The method of historiographical comparative analysis, the historical and comparative method (comparison of objects in time and space) belong to the specific methods that make up the main methodological scientific research tools. Abstract-logical and systematic-structural methods were used for theoretical-methodological clarification of the processes of formation and evolution of categorical concepts and content of separated reserve and regulatory objects in the general system of accounting.
With the help of systemic usage of the following methods, the comprehensive research of materials was conducted with contents of different aspects according to the principles and approaches defined by the JEL Code Classification in the field of scientific and economic research. The chosen methods provide processing of materials related to the block: M41 - Accounting, which is part of M4 - Accounting and Auditing of the section M Business Administration and Business Economics; Marketing; Accounting. The chosen methods allow us to rationally process the materials belonging to block B - History of Economic Thought, Methodology, and Heterodox Approaches, in particular, section B15 - Historical; Institutional; Evolutionary from the History of Economic Thought block. The ideas proposed, like other studies of this type, are based on historiography and source base, and therefore the chosen methods provide block N01 - Development of the Discipline: Historiographical; Sources and Methods from Group N - Economic History.

Various mechanisms and tools for protecting enterprises from the effects of unpredictable negative events in one or another sense are provided in the main financial and economic concepts: model of economic growth (R. Solow), the creation of market value (Modigliani-Miller), the theory of equilibrium (Arrow), the monetary theory (Friedman), the theory of optimum distribution of resources (L. V. Kantorovych), the static and dynamic economic theory (P. Samuelson). Within the framework of non-stop technologies, new terms of management activity were introduced - the Business Impact Analysis (BIA), Business Continuity Planning (BCP), Disaster Recovery Planning (DRP). However, to ensure the practical effectiveness of these concepts, the development of monitoring tools in them as a preventative function is a necessary condition for the "creation of a single reserve, i.e. the aggregate reserves that provide a continuous activity" [1, p. 217]. In such a system, regardless of its classification, shaping of the reserves of capital by accounting plays an important role, as well as an objective reflection of the accrued wear and tear (lost value of the share capital) and depreciation (transferred value of non-current assets). There is no doubt that the system of reserve and insurance 
objects should be created in accordance with the conditions of the general economic environment and the features of the operation of the enterprise, while the reflected loss of stock capital (physical and moral wear) - in line with technological progress.

The classic rule of the economy is that "what is measured and evaluated can be managed" refers mostly to the problems of managing reserves, and therefore accounting information on the value of these objects plays an important role. The same extent applies to information on the residual (lost) value of fixed capital or its estimated real productive value. Accounting belongs to the tools of soft infrastructure of enterprise's management, and therefore the processes of constructing regulatory objects have the appropriate character subordination to the requirements of management system (from the point of view of modern paradigms - risk management). Analytical reviews of the effectiveness of risk management by modern companies, evaluation of the tools of identification and formalisation of the existing and potential risks that were used in these processes confirm the existing problems in the efficiency of risk management embedded in practice (it acquires especially clear obviousness during financial crises). The problematical character of overcoming (mitigation of efficiency) or neutralizing the risks in the post-crisis period makes many experts recognize the importance of accounting, financial reporting, and its audit as important tools of identification and evaluation of risks, an effective mechanism to prevent them.

In the conventional sense, the reserves formalized in the accounting system are considered a source of coverage of possible or expected additional costs or losses formed in accordance with the established methodology. From a financial and economic point of view, it is a question of a real reserve of economic values (liquid assets of tangible or intangible type), created by the enterprise, or cash for specific fixed-purpose insurance purposes. In contrast, under the regulatory accounting, it is expedient in our opinion to recognize the objects that are intended only to refine the assessment of the actual existing assets and capital of the enterprise. After all, from the standpoint of the modern practice, the notion that "the reserves can be characterized as false accounting objects that are created in order to cover possible costs and losses and have the target character use" has been discussed enough in our previous studies [26]. Here, the emphasis is put on the delineated differences of real capital reserves from the estimated, pointing not only to our own opinion, but additionally involving the substantiation of Western Ukrainian scientists in the past regarding the language terms of that time and that are still used regarding the payment from the reserve capital (capital reserves): "payments and return of capital are impossible, payments can be made only with property having the energy that is equivalent of capital. Thus, the reserve capital is only the energy of property that is represented by its own real reserve funds" [17, p. 113];

The wording provided (by which not only content-related understanding is hidden, but also the techniques derived from it) should be recognized as absolutely accurate both in terms of economic matter of this object, and the "classical" methodology of accounting system. At present, reserves are more simply understood to mean "accumulated" profits that are undistributed (blocked from distribution) by a company. However, the capital reserves, hidden by accounting methods, continue to be used in the business environment without any changes. Therefore, reserves in the accounting system created in such a way provide only an imaginary function of information nature, without providing for the separation of the stock of any assets (monetary funds). Historical analysis of the reflection in the accounting of reserving procedures shows that in its origins, the principles of creating reserves were intended to provide not only information support, but also the real formation of the necessary "reserve" of the assets. The critical consideration of modern accounting makes it possible to note that the content of the formation of reserve articles lies in the coordinates of formation of only imaginary reserves (reserve funds as fictitious values). According to modern standardization, it is not really possible to establish whether the valuation article, reserve funds or real capital reserves are indicated in the balance sheet of any modern company. 


\section{Yaremko, O. Lemishovska}

In the vast majority of accounting conventions, the account of reserve capital (in some use of reserve funds) is regarded as such that in real practice, this procedure should prevent back when as a result of loss of property capital (unprofitable financial and economic activities, the impact of factors of the overall economic environment, action of market contractors, etc.) on other capital accounts (accounts of main (charter) capital, as well as accounts of foreign capital (liabilities)) would not be reduced. In fact, in the opinion of the authors of this article, items of protective action on the accounts of reserve capitals can be created from any sources, and not just from profits or operating costs as it is common almost everywhere, - as long as the productive-efficient nature is embedded in them.

The most objective views on the accounting objects "reserves" should include those that consider this object as a source of covering the possible or expected costs or losses of a business entity, representing a real stock of liquid assets, created by the enterprise in accordance with current legislation and internal corporate tactics and strategies, including in the performance of highrisk financial and economic transactions (projects). Proceeding from the peculiarities of the activity of a particular enterprise, the system of such objects is characterized by a special order of formation and the target nature of use. However, there is objectively the complexity of the clear wording of this type of accounts (reserve, regulatory, stock) in practice, as well as the development of formalized methods of calculating the corresponding amounts based on the character and financial and economic validity of creation and proper use of this kind of shell objects for a particular company (the specifics of company's activities, the regulation and stability of the environment of its functioning, the level of social significance of the economic entity, its organizational and legal form, etc.).

To ensure the declared purpose of our research (analysis of past developments and a view from the modern age perspective on the problems and their solution), let's briefly consider the evolution of accounting reserves and regulations. The notion of reserves as an economic category and the object of accounting has been changing, transforming, and acquiring new semantic meanings during history. Not only the content and composition of the reserve funds were changing, as well as the source of their formation, but the purpose of their creation and targeted use changed above all. The information is provided in historical studies that reserves in the balance sheets (in one form or another) had occurred in the 14th - early 15 th centuries already. In the historiographical literature on accounting, it is considered that sufficiently clear delimitation of the conceptual apparatus regarding the accounting view on reserve and regulative objects (balance articles) led the French scientist J. B. Dumarcher. He argued the disposition that in the system of accounting and balance consolidation of reserve objects (liabilities side of the balance-sheet), the active is in contrast to real property value, and the regulator - only to fictitious values. Regarding the evolution of reserves as an accounting object and balance sheet, the following approach is usually followed: at the stage of formation of accounting as a theoretically grounded accounting practice (14th-18th cent.), some enterprises started forming them independently at the expense of profits under the influence of practical necessity: "there was no legal framework, which would regulate the creation of reserves, so the companies had to form at the expense of their own revenue sources to cover the tax needs of the state and warning of bankruptcy - reserves for compensation of damages caused by questionable debts, the estimated reserves of a fiscal nature (for payment of taxes and duties)" [3, p. 68]. In the subsequent stages of the development of the accounting business, the estimated reserves got widespread, producing in general a sufficiently extensive reservation system: accumulation of target resources to cover losses; reserving of financial results for the rearrangement of profits in terms of reporting periods; reserving of financial results to compensate for possible risks and losses in order to reduce the tax base of profit, etc.

With the emergence and development of joint stock companies (19th cent.), there were legislative regulations regarding the formation of reserves as a component of owned capital: "the system of reserves was formed, which consisted of such categories, either confirmed by the Charter or legislatively regulated reserves, as well as the estimated reserves of the impairment of assets, estimated tax reserves (deferred taxes), depreciation, value reserves of target nature; estimated reserves of regulatory nature, hidden 
reserves" [28, p. 11]. During this period and later, the norms on the ratio of statutory and reserve capital were legislatively consolidated. The reservation system in accounting evolved, acquiring a sufficiently voluminous structure: statutory legal reserves; estimated reserves with impairment of assets; estimated tax reserves (deferred taxes); depreciation as a process of creating a new source for the reproduction of fixed capital; target and regulatory valuation reserves; hidden reserves, etc.

In the case studies on contributions to the development of reserve accounting, the works of well-known scientists refer it most often. In particular, A. Zambelli, who suggested the use of accounts for the creation of reserves, also K. Arnold and G. Simon, who substantiated the need to reserve resources to cover losses using the Delkredere account $[11$, p. 67, 73, 239]. From the middle 19th century, various versions are included in the accounting systems of operating contracting accounts and the ones related to them based on the economic content and functional role, which E. P. Leote and A. Gilbo named the "artefact". The accounts Depreciation, Delkredere, Reservations, Regulators started to be applied in the role of objects and in the system of methodical accounting techniques.

With regard to different approaches to the accounting disclosure of capital reserves, then from the financial and economic point of view (capital management of the enterprise), it is fully equivalent (informational equivalence) on which account the data on capital reserves comes into the picture in accounting. Theoretically, the main requirement is that the account of capital reserves should be really balanced with a property account, which shows the productive assets (real assets that are valued in the market). But from a legal point of view, it is important that capital reserves appear on a separate account (reserve capital (reserve funds)), because the members of a closed company or the shareholders of open (public) companies don't have legally justified claims to this type of capital, which cannot be said about the amount of undistributed profits.

The synthesis of static and dynamic approaches, taken as a principle of modern accounting, focused the view on the objects of reserves to a greater extent as regulatory articles. Their use as false objects aims to provide higher objectivity to accounting objects, determined by the accrual method, current market value, changes in estimates, etc. For example, in accordance with IFRS 37 "Provisions, Contingent Liabilities and Contingent Assets", the reserves mean the liabilities with indefinite period of use or with indefinite value. The provisions based on this standard differ from those in which they have a factor of uncertainty as to the maturity or amount of future costs and are used to settle future liabilities in the event of losses. Therefore, the reserves of this type are worth considering as the source of compensation for the adverse effects of risks arising in the process of financial-economic activity (formation (accrual) of reserves - the moment of their acceptance and use does not coincide in time).

The identical categorical concepts are used in the field of accounting, and therefore a considerable part of theoretical studies and practical implementations in accounting during the entire evolution of this system have been sent to objectivization - differentiation of concepts "reserve" and "regulator". There is a number of common features and a thin line of distinctive characteristics between these objects. The common features of reserve and regulatory objects is that information about them is formed on sub-contract accounts, which are usually self-sufficient accounting objects (contractual and counter-passive accounts). Distinctive features of reserves and regulators are the most evident from the standpoint of the following features: 1) reserves are formed at the expense of reduction of gross profits, while the regulators - by means of artificial refinement of the evaluation of opposite balance sheet items; 2) reserve is a counterpart to the existing evaluation of balance sheet items, regulator is a counterpart to the overestimation of balance sheet items; 3) reserves are entered into the balance in order to provide accurate estimate of balance sheet items, regulators - for specification of estimation of balance articles in terms of convenience of practical activity. Scientists are of the opinion that the fund represents accumulation of money that may exceed the capital invested, acting as an additional source, and the reserve does not 


\section{Yaremko, O. Lemishovska}

represent a new accumulation of funds over the available capital. Therewith, the position is often disputed that "the fund is the new accumulation of money and often coming from above the cost of owned capital, while the reserves are usually generated from the accumulated capital (enterprise profits)" [29, p. 229].

Principles and techniques of forming reserves are often mentioned in all the classic balance theories that define their content and functional disposition in the methodological basis of the formed accounting system. The static balance theory in its baseline involves the formation of reserves, when the real obligations in relation to third parties are placed as a basis. In addition, taking into account by this theory of the principle of business activity continuation (static of continuation), the theory in relation to reserves delineates the point of view, which is focused on the liquidation of an enterprise and on the continuity of activities. In the context of the second principle, it is necessary to show the interconnection between the reporting periods that is implemented by the "introduction to the composition of a balance of active and passive anticipations, which today represent either costs or deferred income of future periods" [30, p.11]. Dynamic balance theory is established on the conceptual and methodological basis, which involves creating reserves for covering debt obligations and possible losses, as well as for ensuring future costs and payments. At the same time, the fact that the creation of these reserves should be justified by calculations and have the probable nature of expediency (necessity) of their formation is argued. Organic balance theory involves the creation of accounting and reporting reserves, taking into account the need to maintain the reproductive force (recoverable value) of assets.

The theories stated above, like other wellknown developments have been sufficiently analysed by the general content and specific methods in foreign and domestic research. In this context, it is advisable to elaborate the developments of Western Ukrainian theoreticians and practitioners for the period determined in this study. First of all, the econometric balance theory, produced in educational institutions of Lviv (Lviv Trade School) in 1910 should be separately represented. This theoretical (accountingeconometric) development positions the process of creating capital reserves (reserve as a technical accounting method) for balancing the real property value and capital (accommodation counterbalance of property and capital) of an economic entity. In this theory, based on the primary and secondary econometric equations with the exit to the econometric quadrigue and economic octagon, the system of accounting reservation is substantiated: "a part of the net profit is sent to the reserve fund, and thus the part of the property is connected through the allocation of equal energy to it and it is given a form of reserve capital for our knowledge" [17, p. 114].

Representatives of Western Ukrainian accounting in their past scientific publications [17, $18,22]$ formulated and substantiated (within the concepts of German accounting thought) postulates that strong financial position of the enterprise depends on the amount of reserves (the higher is the proportion of reserves, compared with the registered capital, the stronger is financial position). On the basis of this postulate, we have developed practical approaches to evaluation of sources of enterprise resource formation (productive power of capital), which, in our view, should be also used in the parameter of the modern financial and economic environment in the processes of constructing balance sheet analytical characteristics. During the considered period the most prominent in Galicia theoretical development in the field of accounting, including reserves accounting methods, was the work of Richard Reisch and Klemens Kreibig "Balance sheet and tax" (Bilanz und Steuer. Richard Reisch und Klemens Kreibig: I Band, Wien 1907; II Band, Wien 1909). However, in practice suggested in it methodological and conceptual foundations were hardly used, since these developments (II, p. 67) assumed that "reserve funds are the part of assets intended for distinct preservation without current use; they are actually own assets, including original net ones, not just their increase". That is, any assets, not only income, could be the source of the reserves formation.

The use of income as a source of reserves was considered as its part retained "to strengthen the funds (assets) and also against possible losses 
in future", which is still debatable in terms of the possibility to increase resources productive energy through this accounting procedure. In a follow-up to their statement, Western Ukrainian scholars attempted to justify differences between the reserve fund in its traditional sense (a separate part of capital (reserve capital as a result of recapitalization)) and, by their definition, actual (real) funds (capital). It has been argued that in the first case, the reserved assets, used by the enterprise, are in fact visible only to the inspection bodies, and in real practice such reserve funds often have no value and, therefore, they are not capital [17, 21, 22]. In order to achieve the purpose of creating a real reserve capital a distinct management of assets was proposed, moreover, these assets should be reflected in a separate balance sheet. Such assets involved primarily the acquisition and holding of securities for such purposes.

Accounting techniques that implied only changes in capital items were critically assessed by the Eastern Galicia theoreticians. They came to the conclusion about inability to navigate in reserve funds in this case: "if this was the subject of legislation, then it would be necessary not only to adjust precisely the nomenclature of these funds, but also to prohibit completely improper or fictitious reserve funds" [17, p. 46]. The necessity of more rigid imperative regulation of reserve funds on the condition that enterprise undertake reserve assets management themselves was demonstrated on a typical example of the Imperial and Royal Supreme Court decision of December 20, 1906 (Beispiel einer Entscheidung des k.k. Obersten Gerichtshofes). On the basis of this decision the following example was given in the accounting literature: the guarantee funds (Garantiefonds), which were fictitious but were considered as paid in the amount of 150000 crowns, were not able to cover the loss for the same amount.

Galician accounting academics supported the accounting proposal that earnings from such type of capital reserves should be attributed to incomes and losses, as it was suggested by Robert Stern in the well-known Austro-Hungarian Encyclopedia of Accounting (R. Stern. Buchhaltungs - Lexikon. Wien und Leipzig, 1902).
Against the background of the above analysis of past developments of world and Western Ukrainian theorists, practical methods of accounting for reserves, we should note that in today's accounting the following groups of reserves are reflected in the balance sheet: bad debt reserve; provisions for expected future expenses and payments; reserves for impairment of assets (securities); reserve capital (coverage of operating (balance sheet) losses and expenses); capital reserves (special-purpose reserve funds) deduction of a special purpose from the net income or financed out of the expenses for expected losses covering, compensation of risk and other expenses, which arise in the course of financial-economic activity and at profit distribution. In different countries the system of reserve objects is traditionally different. For example, in the paper [30] the liabilities and owner's equity side of the Germany balance sheet was presented, where besides registered capital (I), additional/reserve capital (II) is shown, and in Section III, "Reserve funds formed at the expense of income", the following items are presented: 1) mandatory reserves; 2) reserve for own shares; 3 ) reserves created in accordance with the constituent documents and 4) other reserves formed at the expense of income. In addition, information about target valuation reserves is provided in section $V$ of the balance sheet: 1) the reserve for pension payments; 2) the reserve for tax payments; 3) other reserves.

Growing importance of the modern subjects of market economy (companies, corporations) objectively predetermines the need for the formation and use of reserves of socio-economic character for capital insurance: the reserve for employees' participation in incomes; additional pension funds; special pension funds, etc. The creation of this type reserve subsystem should be the focus of attention for the theorists and practitioners in the field of accounting, thus, in our opinion, the necessary condition is the creation of a regulatory framework and imperative prescriptions regarding the formation of reserves for the pension funds protection.

On the basis of the analysis of the world historiographical literature, the elaboration of the Western Ukrainian theorists and practitioners developments, the existing contemporary well-known 


\section{Yaremko, O. Lemishovska}

issues in the field of reserves accounting for, we propose the following interrelated system of the main and reserve (insurance) objects in the balance sheet presentation of the enterprise capital (Fig. 1).

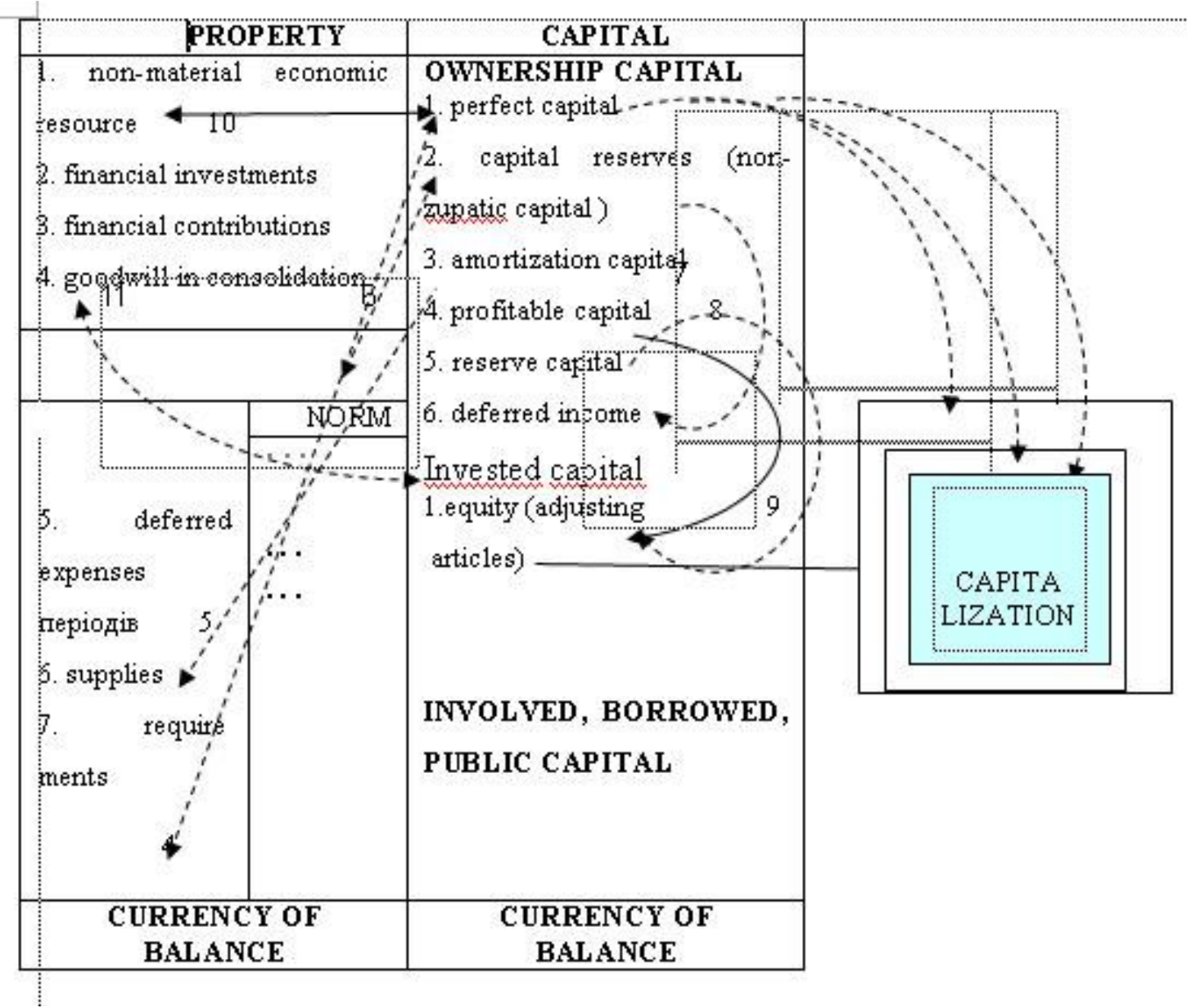

Fig. 1. Intercommunication and the interdependence of economic resources and constituents of capital for constituents of capital for establishment an indicator of reproductive

In this model dependence of market constituent of enterprise capital from assessment of its potential capacity market mechanism is monitored $(1,2,3)$. At the initial public offering, next emissions, in different periods of time the index of boundless constituent of capital changes and on the isometric sum nonmaterial economic resource of enterprise (10) in part of common define and internal corporate goodwill. Interdependence of maximum limit of non-material constituent from the "real" size of enterprises assets was marked by pointer 4 (fair value of the business property).

Pointer 5, which connects the existing enterprise requirements (account receivable) with the creation of appropriate capital reserves as anticipation (expectation of non-payments crisis in conditions of economy stagnant), that should prevent the problems of managing a floating capital.

Capital reserves (pointer 6) should provide abnormal supplies of material values and prepared products, deferred expenses and also to insure doubtful and hopeless account receivable. Such reserves are expedient, in addition, to balance with the size of deferred income, part of which also does not have the proper legal and financial provision (pointer 7). Such revenues in previous periods were included in the calculation of indexes, including indexes that characterize the cost of enterprise. It is suggested (pointer 11) to counterbalance equity with purchased goodwill in consolidation. The offered scheme foresees redemption of fictitious assets that arise up at the fact of purchasing goodwill (extrapolation of results is the overpriced 
expectations) in a modern economy by reducing the risk of equity losses.

Profit, as an additional cost of invested capital should reflect its direct dependency with the size of market value of this capital (conception of preservation the financial capital) and that is why it must be determined on such basis and meddle with the size of equity in the end of reporting period (pointer 8).

The legislative adjusting of creation the reserve capital should have stricter regulations. Reserve capital that is created according to legislative regulations due to profit, in unprofitable enterprises is absent. Equity remains unprotected in this case, so obviously it needs to increase the protective power of this instrument considered the fundamental and other objects of its creation (base of extra charge) (pointer 9).

As part of the proposed system of reserve and regulatory articles depreciation and amortization is also considered. In accounting practice there were always two concepts, which are close but at the same time different by economic meaning - "depreciation" and "amortization" of fixed assets. The dominant postulates of depreciation and amortization of fixed assets' reflection in accounting and reporting are based on the idea of the French scientist Dumarchey J. B., who substantiated the amortization as a regulative rather than the reserve and therefore amortization should be equal to the depreciation amount. In spite of various methodological approaches (distinctive accrual on accounts of depreciation and amortization, synthesized combination of these objects in the accounting system) the amount of accrued amortization and depreciation has always been determined as identical.

In accounting amortization was associated with the transfer of property value to a newly created product and the depreciation was interpreted from the standpoint of object's cost reduction (wear and tear or obsolescence). In particular, Matheson pointed out that "depreciation" was initially introduced into practice as a shortened version of the "diminution of value by reason of wear and tear" concept [2, p. 285]. In today's international standardization there are two standards - IAS 16 "Property, Plant and Equipment", which describes amortization and discloses mechanisms for its calculation and IAS 36 "Impairment of Assets", which describes the appropriate process of accounting object's book value change.

Critically assessing the current methodology for amortization and depreciation of non-current assets some scholars adhere to an extremely critical view: "Nowadays in the domestic theory and practice instead of methodological substantiation of the essence of fixed assets' "depreciation" and "amortization" eclectical approach is applied by combining diametrically opposite interpretations of the famous scientists of late nineteenth and early twentieth centuries" [32, p. 63]. The impact of modern approaches to depreciation and amortization calculation on the book value of an economic entity is deeply disclosed in the paper [33] and the impact of different accrued amortization amounts depending on the used method on calculated financial results' amount in the article [34]. In order to improve the accounting of amortization and depreciation as a result of obsolescence [35] "the methodological bases of fixed capital obsolescence accounting and reporting reflection of corporations are offered". The proposed method involves "the creation of an appropriate capital reserve functionally aimed at ensuring the protection of a market-determined share capital from reduction" [35, p. 5].

The study of well-known foreign authors' views is sufficiently given in historiographic sources. However, developments of Western Ukrainian scholars are not given at all. In particular, we note that in accounting field developments of Lviv scientists more than 100 years ago attention was drawn to the discrepancy in the calculation of amortization (depreciation) and capital loss: "The difference of initial value and value after one year should be written off (amortized), econometrically which is nothing but a reduction of property and capital ... with the traditional depreciation accrual this second economic action is completely absent" [17, p. 25].

Problems of property amortization and depreciation reflection in accounting took a significant place in works of Western Ukrainian theorists. Thus, in the manual for trade schools [21] problems of amortization and depreciation are disclosed in the section "Accounts for asset 


\section{Yaremko, O. Lemishovska}

components" (in original "O rachunkach dla składników majątkowzych (rachunkach zapásowych)"). More widespread problem aspects of the accounting methods of depreciation and amortization are given in the work [17]. They are researched in Section 5 "Property and Capital" (in original "Vermögen und Kapital") as well as in Section 6 "Economic Actions" (in original - Die wirtschaftlichen Handlungen) where the change in property and capital value as a result of property cost reduction during operation is considered. These accounting procedures in the work are considered through the objectivity of "The ratio of assets to capital" (in original - Das Verhältnis des Vermögens zum Kapital) method. General impact of amortization and depreciation on the capital cost is reasonable to conduct on the basis of proposed accounting methods of "Changes in the value of assets and capital" (in original - Die Wertveränderungen des Vermögens und Kapitals). In works were used different approaches to the development of more objective methods for property amortization. For example, in the textbook [15], such accounting approaches are considered through "Property Components" (in original Części składowe majątku), which are proposed to be solved on the basis of "Assessment or marking of property components' value" (in original - Szacowanie czyli oznaczenie wartości części składowych majątku).
The new context of amortization accounting reflection is associated with attempts to link accumulated amortization (formed amortization fund) with fixed assets reduction due to assets' wear and obsolescence equipotentially. Under inflation, as well as a result of the technological progress of some production means rapid replacement by others appeared a problem of information from Balance on the objectivity of fixed assets' residual value, sources of non-current assets reproduction, the reliability of calculated amortization accruals as a part of costs to real loss of consumer value. A modern enterprise as a complex multidimensional economic system is considered in the coordinates of value assessment, in particular, according to the criteria for the preservation of subscribed share capital and the distribution of created value. The value of modern corporation capital should be considered not only from the point of view of self-increasing value, but also taking into account the physical and moral depreciation of tangible and intangible assets, representing the amount of capital. The loss of economic resources of their market value objectively reduces the value characteristics of the company's equity, which significantly increases the requirements for the development of adequate for the modern economy principles of depreciation and amortization of non-current assets. Interdependence of reversal flows of capital assets and reduction "weakening" of share capital is shown in Figure 2.

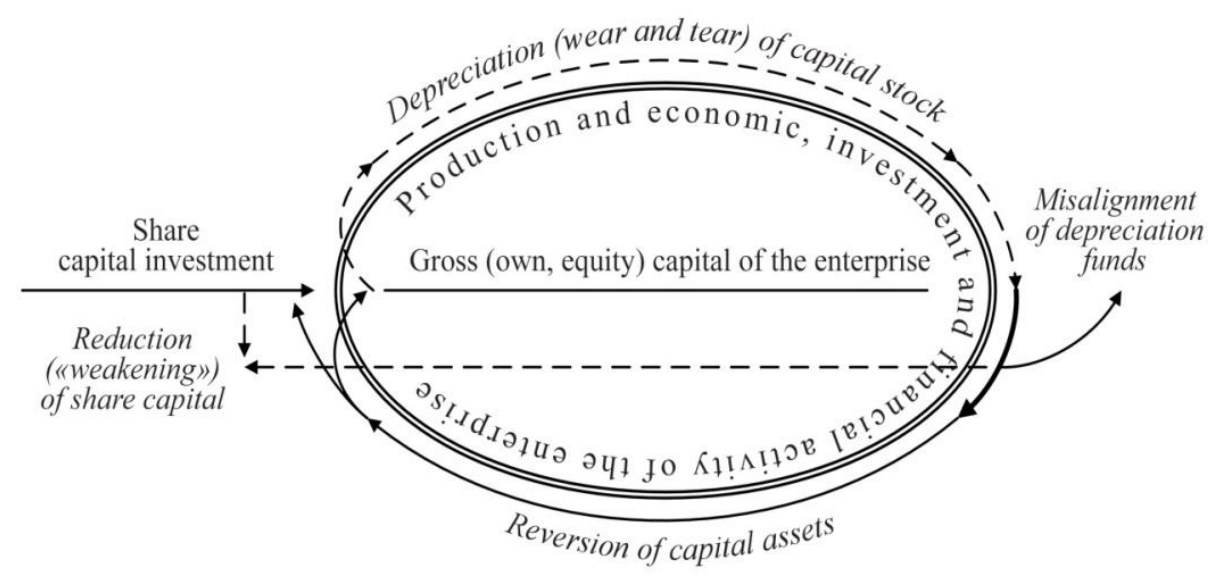

Fig. 2. Interdependence of the share capital value with the target direction of depreciation sources

Capital reserves (pointer 6) should provide abnormal supplies of material values and prepared products, deferred expenses and also to insure doubtful and hopeless account receivable. Such 
reserves are expedient, in addition, to balance with the size of deferred income, part of which also does not have the proper legal and financial provision (pointer 7). Such revenues in previous periods were included in the calculation of indexes, including indexes that characterize the cost of enterprise. It is suggested (pointer 11) to counterbalance equity with purchased goodwill in consolidation. The offered scheme foresees redemption of fictitious assets that arise up at the fact of purchasing goodwill (extrapolation of results is the overpriced expectations) in a modern economy by reducing the risk of equity losses.

Profit, as an additional cost of invested capital should reflect its direct dependency with the size of market value of this capital (conception of preservation the financial capital) and that is why it must be determined on such basis and meddle with the size of equity in the end of reporting period (pointer 8).

The legislative adjusting of creation the reserve capital should have stricter regulations. Reserve capital that is created according to legislative regulations due to profit, in unprofitable enterprises is absent. Equity remains unprotected in this case, so obviously it needs to increase the protective power of this instrument considered the fundamental and other objects of its creation (base of extra charge) (pointer 9).

Modern standardization (IAS, CAAP) of financial reporting in general and in particular, the balance is becoming more dependent on private-corporate motivational aspects but not financial and economic canons of theory and actual economic reality. The acceptance of certain format of balance has financial, economic and property consequences which are beneficial or not beneficial to certain groups of participants (management, shareholders, society, government and others like that). Prevailing of multinational corporations and different political forces in the separate state influence on a decision in the field of balance. This factor is well monitored on the basis of development the balance theory that finds direct expression in regulations of the International standards of financial reporting which is a combination of a little bit constrained positions, assumptions and principles, not ranged in a hierarchical structure. It is not clear which of provisions are basic and primary, and which are derivative.

The first of problem questions is absence of standard "Property asset" part of which is "retained earnings". IMF now acknowledges that the adopted rules of financial reporting, corporate finance created "blurred indexes of estimation the default risk of portfolio investments" and that a fair value "regulates market instability" (look in IMF, Containing Systemic Risks and Restoring Financial Soundkess, op cit. p. 64, 65). It is possible to mark that retreat of leading financial investments from still profess axiomatic approach in economic science.

There are a lot of development problems in economic science. With the collapse of capital markets, economic stagnation the turbulent Hosanna newest systems had subsided, models and tools and at the same time Requiem for a "liberal economy" and post-modernism methodology became obvious. Economists of "mainstream" and adherents of theoretical and methodological pluralism under pressure of religions of the financial and economic crisis were forced substantially to look over the set forth conceptual principles of economic science. On different levels (practical, theoretical, scientific) provides discussion about the necessity of creation the format "post-crisis model of business" which requires substantially different conceptual, methodological and methodical principles of financial and economic science. It goes both about ontology (theoretical character of economic reality) and by a gnosiology (process (sources, possibilities and facilities) of cognition). Now it becomes quite obvious that economic science lost the theory summarizing, integral system and corresponding method that were resulted the loss of system criterion, choice of which became partial and limited. Fata Morgana character of many developed theories, mimicry of capital image became the "curse of winners" for a lot of well-known companies in the world.

\section{Conclusions}

Real practice, not forecast of fund markets and capital markets, lack of satisfactory scientific explanation and grounds after methodologies of the formed systems and models of cost estimation 


\section{Yaremko, O. Lemishovska}

imposes requirement to develop significantly new principles and on the basis of improving the conceptual foundations of evaluating the cost parameters of the enterprise.

Use of mine-out principles in the formed systems of cost indexes as tools of the market mechanism, theoretical and practical principles of cost management that is connected with withstand and stable corporate and financial relations in the conditions of economic stagnation require new principles of forming the conceptual approaches and perfection the methodological bases of cost evaluation the enterprise and business, scientific validity of this process. According to such initial bases of improving the national assessment system of cost characteristics of the enterprise is also considered by the adaptation of methodological principles of evaluation procedures, approaches, methods and subordination of evaluation categories to the terms of the real economy.

Because of failures in assessing the cost parameters for big amount of subjects the technically-methodical and informational-analytic formed base can't consider as reliable instrument of analysis the cost changes in an economy. For providing the conception is required in the improvement of the methodological foundations of economic factors of measuring value and grounded on the synthesis of the formalized basis of financial indexes and not financial indicators.

\section{References}

1. Krutova, A., \& Tarasova, T. (2016). Oblikovoanalitychne zabezpechennia upravlinnia rezervamy yak dzherelamy pokryttia ryzykiv [Accountinganalytical provision of management of reserves as a source coverage of risk]. Ekonomichnyi prostir Economic scope, 115, 212-224 [in Ukrainian].

2. Mathews, M. R., \& H. Perera. (1999). Teoriya bukhgalterskogo ucheta [Accounting Theory and Development]. (E. I. Gogiy, Ya. V. Molotok, I. Smirnova, Trans.). Moscow: UNITI [in Russian].

3. Vashchenko, V. V. (2015). Istoriia rozvytku systemy rezervuvannia [History of the system of redundancy]. Naukovyi visnyk Uzhhorodskoho universytetu. Seriia "Ekonomika" - Scientific bulletin of uzhhorod university. Series "Economics", 1(45), 2, 68-71 [in Ukrainian].

4. Gaiduk, I. S. (2016). Teoretychni aspekty formuvannia rezerviv $v$ systemi bukhhalterskoho obliku [Theoretical aspects of provisioning in accounting] Ekonomichnyi visnyk universytetu University Economic Bulletin, 31(1), 130-136 [in Ukrainian].

5. Pikush, Yu. V., \& Pylypenko, L. M. (2012). Pryntsypy formuvannia rezerviv $u$ systemakh bukhhalterskoho obliku [Principles of formation of reserves in accounting accounting systems] Visnyk Natsionalnoho universytetu "Lvivska politekhnika". Seriia: "Menedzhment ta pidpryiemnytstvo $v$ Ukraini: etapy stanovlennia i problemy rozvytku" Journal "Management and Entrepreneurship in Ukraine: the stages of formation and problems of development", 721, 211-215 [in Ukrainian].

6. Shchyrska, O. V. (2013). Ekonomichna sutnist poniattia "amortyzatsiia" ta "znos": istorychnyi aspekt [The economic essence of the concept of "depreciation" and "depreciation": the historical aspect] Problemy teorii ta metodolohii bukhhalterskoho obliku, kontroliu $i$ analizu: mizhnarodnyi zbirnyk naukovykh prats - Problems of theory and methodology of accounting, control and analysis, 2(20), 478-485 [in Ukrainian].

7. Kulikova, L. I. (2015). Bukhgalterskaya kontseptsiya amortizatsii: istoriya stanovlennya i razvitiya [The accounting concept of depreciation: history and development] Mezhdunarodnyy bukhgalterskiy uchet - International accounting, 37, 2-15 [in Russian].

8. Kozlova, O. M. (2004). Rezervy, zabezpechennia, rehuliatyvy: sutnist ta problemy terminolohii [Provisions, provision, regulation: the essence and problems of terminology] Visnyk Zhytomyrskoho derzhavnoho tekhnolohichnoho universytetu. Seriia: Ekonomichni nauky - The Journal of Zhytomyr State Technological University. Series: Economics, 1(27), 81-89 [in Ukrainian].

9. Ponokova, D. I. (2007). Bukhgalterskiy uchet rezervov i regulyativov [Accounting reserves and regulators] Extended abstract of candidate's thesis. Krasnodar [in Russian].

10. Orischenko, M. M. (2009). Oblik i audyt rezerviv kapitalu: metodolohiia ta orhanizatsiia [The accounting and auditing of reserves of the capital: methodology and the organization]. Extended abstract of candidate's thesis. Kyiv [in Ukrainian].

11. Sokolov, Ya. V., \& Sokolov, V. Ya. (2004). Istoriya bukhgalterskogo ucheta [Accounting history]. Moscow: Finance and statistics [in Russian].

12. Chenaux-Repond, J. (1924). Kaufmännische Bilanz. Bücherabschluß-Steuerbilanz. - Stuttgart.

13. Romer, A. (1923) Die Werterhaltung in der Unternehmung und das einschlägige Steuerrecht.Berlin. 
Reserve and regulatory objects in accounting theory and practice: origins and evolution...

14. Pietrzycki, E. (1886). Nauka teoretyczna $i$ praktyczna rachunkowości, czyli buchalterii kupieckiej pojedynczej $i$ podwójnej do użytku szkolnego i domowego, (Vols. 1). (2nd ed., rev) Lwów: nakładem księgarni J. L. Pordesa.

15. Au, Juliusz. (1899). Nauka rachunkowosci dla potrzeb cospodarstwa wiejskiego zastosowanej. Lwow: I. Zwiazkowa drukarnja we Lwowe.

16. Lenkiewicz, W. (1905) Rachunkowość pojedyńcza $i$ podwójna (dla wiekszej własnosci ziemskiei). Lwów: Drukarnja i litografia Pillera i Spolki.

17. Ciompa, P. (1910). Grundrisse einer öekonometrie und die auf der Nationalökonomie aufgebaute natürliche theorie der buchhaltung; ein auf Grund neuer ökonometrischer Gleichungen erbrachter Beweis, dass alle heutigen Bilanzen falsch dargestellt werden Verlag des Handelsschulvereines in Lemberg. Lemberg: Druck von Artur Goldman in Lemberg.

18. Góra, W. (1913). Podręcznik nauki buchalterii. Buchalterya podwójna $i$ jej zastosowanie $w$ różnych gatęziach handlu i przemystu. (Vols. 3). Lwów: nakładem Towarzystwa Nauczycieli Szkót Wyższych, E. Wende i Ska;

19. Góra W. (1917). Nauka książkowości (buchalterya). Książkowośc podwójna $i$ jej zastosowanie w handlu towarowym. (Vols. 2), (2nd ed., rev). Lwów: Drukarnja przy Zakladzie narodowym imienia Ossolinskieh.

20. Pawtowski, A. (1918). Rachunki kupieckie dla szkót handlowych. (3th ed., rev). Lwów: Książnicy towarzystwa Nauczycieli szkót wyższych we Lwowie.

21. Góra, W. (1921). Podrecznik księgowości: księgowość pojedyncza. (Vols.1), (3th ed., rev). Lwów-Warszawa: Ksiązinica towarzystwa Nauczycieli szkół wyższych we Lwowie.

22. Tomanek, F. (1932). Wartość w economice a $w$ bilansach. Streszezenie wykładu inauguracyjnego, wygłoszonego $w$ dniu 16 pażdziernika 1932 r.w wyższej szkole handlu zagranicznego we Lwowie. Odbitka z księgi zbiorowej p.t.: "Życie gospodarcze a ecjnjmika społeczna”. (Vols.2). Lwow: Bibljoteki Polskiego Towarzysiwa Economicznego we Lwowie.

23. Bartynski W. (1937). Temat do ksiegowośći $w$ przedsiebiorstwi detalicznym. Lwow: W-wo Zakladu Narodoej im. Ossolinskich.

Gorniak, S., \& Paszek, L. (1938). Ksiegowosc w handle detalicznym. Lwow: Panstwowe wydawnictwo ksiazek szkolnych we Lwowe: odbito $w$ drukarni B. Polonieckiego we Lwowe.
26. Eremenko, T. V. (2013) Razvitiye ucheniya ob amortizatsii $v$ Germanii [The development of depreciation studies in Germany] Finansy i biznes - Finance and Business, 3, 116,123 [in Russian].

27. Yaremko, I. J. (2002). Ekonomichni kategorii v metodologii obliku [Economic category in accounting methods]. Lviv: Kamenyar [in Ukrainian].

28. Hendriksen, E. S., \& Van Breda, M. F. (1997) Teoriya bukhgalterskogo ucheta [Accounting Theory]. Ya. V. Sokolova (Ed.). (Ya. V. Sokolova, Trans.). Moscow: Finance and statistics [in Ukrainian].

29. Veryha, Yu. A., \& Oryshchenko, M. N. (2011). Rezervuvannia kapitalu: oblik, audyt $i$ zvitnist [Capital provision: accounting, auditing and reporting]. Poltava: EPD PUET [in Ukrainian].

30. Krupka, Ya. D. (2001). Oblik investytsii [Accounting for investments]. Ternopil: Economichna dumka [in Ukrainian].

31. Bethge, Y. (2000). Balansovedenie [Balancing] V. D. Novodvorskiy (Ed.). (V. D. Novodvorskiy, Trans.). Moscow: Accounting [in Russian].

32. Zhuravel, H. P., \& Khomyn, P. Ia. (2008). Teorii bukhhalterskoho obliku: studii [Accounting theories: studios]. Ternopil: Economichna dumka [in Ukrainian].

33. Sokolov, Ya. V. (1999). Bukhgalterskiy uchet: ot istokov do nashikh dney. [Accounting: from the sources to our day]. Moscow: Audit UNITI [in Russian].

34. Lemishovska, O. S. (2017). Economic categories of "amortization" and "depreciation": the history of accounting concept formation and development. Baltic Journal of Economic Studies, 3(5), 260267. DOI: 10.30525/2256-0742/2017-3-5-260-267.

35. Lemishovska, O. S. (2018). Finansovi rezultaty: retrospektyvnyi analiz rakhivnychoi praktyky, oblikovykh kontseptsii $i$ metodyk [Financial Results: Retrospective Analysis of Bookkeeping Practice Accounting Concepts and Methods]. Oblik $i$ finansy - Accounting and Finance. 3(81), 45-53. [in Ukrainian].

36. Pylypenko, L. M. (2016). Rozvytok kontseptsii pobudovy systemy publichnoi zvitnosti korporatsii $v$ umovakh postindustrialnoi ekonomiky [Development of concepts for building a system of public reporting of corporations in a postindustrial economy]. Lviv: Publishing House of Lviv Polytechnic National University [in Ukrainian]. 